\title{
O professor que nunca tive, mas tenho até hoje
}

\author{
José Geraldo Couto ${ }^{1}$
}

${ }^{1}$ Formado em história e em jornalismo pela USP, é crítico de cinema, jornalista e tradutor. Trabalhou durante mais de vinte anos na Folha de S. Paulo e três na revista Set. Publicou, entre outros livros, André Breton (Brasiliense), Brasil: Anos 60 (Ática) e Futebol brasileiro hoje (Publifolha). Participou com artigos e ensaios dos livros $O$ cinema dos anos 80 (Brasiliense), Folha conta 100 anos de cinema (Imago) e Os filmes que sonhamos (Lume), entre outros. Escreve regularmente sobre cinema para a revista Carta Capital e mantém uma coluna de cinema no blog do Instituto Moreira Salles. 
Nunca fui aluno de Ismail Xavier. Mas sempre fui aluno de Ismail Xavier. Por volta de 1980, eu cursava jornalismo na ECA quando, numa manhã qualquer, um colega avisou: "Vai passar Alphaville no auditório da escola". Eu já tinha visto o filme, mas assisti-lo de novo era sempre uma alternativa mais atraente do que uma aula de jornalismo sindical, técnicas de reportagem ou coisa que o valha. Pois bem: não era uma simples sessão de cinema, pois o professor que apresentava o filme era Ismail Xavier, de quem até então eu só ouvira falar.

$\mathrm{Na}$ conversa que se seguiu à exibição, Ismail não só fez uma exegese precisa do filme como o relacionou à Nouvelle Vague e aos cinemas novos em geral, mostrou sua influência sobre $O$ bandido da luz vermelha de Sganzerla, abriu mentes, portas, janelas, horizontes. Um professor, em suma.

A partir de então, passei a ler todo e qualquer texto de Ismail que me caísse nas mãos, além de assistir, sempre que possível, a suas palestras. Mas só tive coragem de me dirigir a ele anos depois, já como jornalista profissional. Descobri, então, um sujeito tão acessível e sem frescura que lamentei não ter me aproximado antes.

De todo modo, já fazia anos que ele conversava comigo, por meio de seus livros e ensaios brilhantes sobre Glauber Rocha, Griffith, tropicalismo, underground, teorias do cinema (muitas das quais ele ajudou a difundir e discutir no Brasil), etc.

O que sempre me impressionou em Ismail foi reencontrar em qualquer intervenção sua, do artigo de jornal à tese de grande fôlego, da conversa informal à conferência acadêmica, a mesma postura generosa e pedagógica - no melhor sentido - daquela primeira sessão comentada de Alphaville. Uma inteligência compartilhada, um desejo de colocar na roda descobertas e dúvidas, difundindo o conhecimento como uma forma de prazer.

Quando passei a escrever profissionalmente sobre cinema - ainda que na superficialidade da imprensa - passei a invejar também a desenvoltura com que Ismail combina a análise cerrada da forma de cada filme com a discussão de suas articulações históricas, culturais e políticas. Não por acaso seus mestres foram 
Paulo Emílio e Antonio Candido, pensadores da cultura que nunca dissociaram a arte da sociedade que a produz, sem com isso reduzir a primeira a uma consequência ou reflexo da segunda. Com sua voz própria e seu estilo original, é a essa nobre estirpe que pertence Ismail Xavier. 